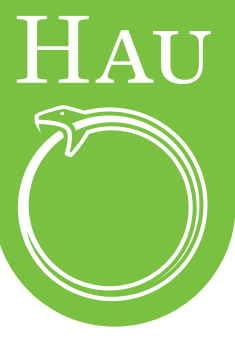

\title{
Elephants as persons, affective apprenticeship, and fieldwork with nonhuman informants in Nepal
}

\author{
Piers Locke, University of Canterbury
}

In this account of interspecies intimacy in the enclaved institution of the Nepali elephant stable, I explore not-just-human figurations of personhood and argue for the methodological inclusion of nonhuman informants as subjective actors and contributing participants in ethnographic research. I explain how my experience forming a trusting, working relationship with a female elephant in a hybrid community of humans and elephants revealed the conceptual limitations of a human-focused tradition of ethnography ill-equipped for the generative sociality of interspecies encounters. I discuss questions of nonhuman personhood and I consider developments in the animal behavioral sciences, while also investigating the cultural logic by which Nepali mahouts attribute personhood to their elephants. This exploration of apprenticeship, personhood, and affective encounter is situated in a distinctly interspecies strand of multispecies studies, and is a contribution to ethnoelephantology as an interdisciplinary approach to the social, historical, and ecological relations between humans and elephants.

Keywords: apprenticeship learning, human-elephant relations, nonhuman personhood, multispecies studies, ethnoelephantology, mahouts, Nepal

It is 5 a.m. and as I open the door of my hut I see Sitasma Kali and Kha Prasad silhouetted in the wintry mist. Mother and baby are waiting as usual, tethered to their post, ready for the first duty of the day: grass cutting. Barefoot, armed with a stick and a sickle, and carrying a sack to sit on, I approach my elephant companion. As usual, she extends her trunk, curling it around me for an olfactory probing in what has become a communicative ritual of loving trust. Her warm breath caresses my skin as my hand 
strokes the delightful grooves of her many-muscled trunk. She is the only elephant I submit myself to in this way. Another could easily respond with violent animosity.

I give the command "baith!" and Sitasma descends delicately, crouching on her knees. I remove the sikri (tethering chain) that connects her right foot to the kambha (post), and put a kasni (neck chain) around her large, wrinkled neck. I use the sack to gently beat the dust off her, and then I make the gesture of supplication that connects my head and my heart to her divine body. Now I am ready to mount her. I am sitting on a sack on her neck, positioned between the hairy crown of her head and her bony shoulders. I insert my feet into the atargal (braided stirrups) that connect to the kasni. Now I am ready to apply my toes to the soft skin behind her ears, establishing a kinesthetic union of human and elephant. I shout "maiel!" Sitasma stands, and I depress my toes to communicate a request to move forward. Accompanied by her infant son Kha, we plod off toward the river, beyond which lie the grasslands where we will cut fodder for the day.

The human-elephant relationship intimated here is not just a peak experience from the ethnographic odyssey of an anthropologist in a culturally foreign space. It also represents a privileged form of intimate, interspecies relations rarely subject to ethnographic inquiry. By thinking about human-elephant relations in terms of intersubjective interactions, considering elephants as persons or near-persons with whom one produces social relations, my ethnography raises questions about human exceptionalism in ethnographic methodology. This exceptionalism is evident in humanist scholarship that suggests humans alone can be disregarded from the webs of interspecies dependency by which we understand other life (Haraway 2008: 11). Posthumanist critiques of the ways in which humanity has been conceptually segregated from other life forms are relevant here (Castree et al. 2004), as are the biocultural sciences of sentient and socially complex mammals that suggest culture, in the qualified sense of socially acquired and transmitted knowledge and behavior, is not unique to humans (Byrne et al. 2004).

These challenges to the conceptual binary of the cultural human and the natural animal inform many ethnographies of shared life that are emerging in response to both the ontological insularity of humanism and the ecological de-contextualization that it encourages (Latour 1998: 16). Unlike previous work in the socio-cultural anthropology of human-animal relations (see Mullin 1999), this work seeks to overcome the compartmentalizing limitations of the "two cultures" of the sciences and the humanities by attending to disciplinary knowledge from both domains. This posthumanist "multispecies turn" also exceeds an exclusively zoological concern, recognizing that even primarily dyadic interactions between human and nonhuman animals involve other kinds of living agents, as Celia Lowe and Ursula Münster (2016) demonstrate with regard to humans, elephants, and the herpes virus, for instance.

Applying insights from the sciences and the humanities, theorists have been arguing that not only humans engage in semiosis (Kohn 2013), that not only humans exercise meaningful agency (Kirksey and Helmreich 2010), that we should recognize that human life is constituted not in opposition to but through relations with animal others (Lestel and Taylor 2013: 183), that humans construct their social and 
ecological niches in consort with companion species (Fuentes and Kohn 2012), and therefore that there can and should be an "anthropology beyond humanity" (Ingold 2013). These are just a few key assertions from a more-than-human approach gaining traction in the humanities and social sciences, perhaps most evident in anthropology, geography, and science and technology studies (Locke and Münster 2015). Indeed, the concerns and perspectives shared by such discipline-specific developments as "multispecies ethnography" (Kirksey and Helmreich 2010; Ogden, Hall, and Tanita 2013), "more-than-human geography" (Whatmore 2006; Panelli 2010), and even "transspecies history" (Nance 2013; Baker 2016) warrant recognition of a more inclusive discursive space. This has now been advanced with the proposal for "multispecies studies" recenty made by Thom van Dooren, Eben Kirksey, and Ursula Münster (2016). The authors argue that we should "cultivate arts of attentiveness" by embracing a range of approaches for knowing and understanding others, by unsettling given notions, by considering modes of classifying and categorizing, and by considering the ways in which forms of life constitute worlds in consort, an agenda that informs the concerns of this article.

Informed by a conceptual tool kit that emphasizes mutuality, becoming, and entanglement, multispecies studies represents a site for a diverse array of work that helps to reframe knowledge and redirect understanding through explorations of multispecies networks and interspecies interactions. Anna Tsing and colleagues, for instance, collaboratively elucidate the connections between humans, pine forests, and matsutake mushrooms in economic and ecological processes involving knowledge, livelihood, and commodification at multiple sites (e.g., Choy et al. 2009; Tsing 2015). Marcus Baynes-Rock, by contrast, explores a particular dyadic relation between humans and hyenas at the singular site of Harar, Ethiopia, where these bone-eating scavengers uniquely share urban space with human city dwellers (2015). These cases, the first focusing on multiple, networked agency, the second on intimate interspecies relations, indicate the divergent possibilities of multispecies studies in terms of scope, focus, and method, while sharing a concern with the ways in which humans advance their projects and make their worlds with nonhuman others that are conceived as more than merely passive biotic and semiotic matter. Perhaps the crucial distinction here is between the presence or absence of interactive subjectivities, at least as our zoocentric perspective inclines us to recognize. Indeed, it is now possible to recognize a particular strand of multispecies studies that focuses on interspecies intimacies, often through productive engagements with the animal behavioral sciences (for a literature review of multispecies ethnography, its allied approaches, its particular trajectories, and formative theoretical resources, see Locke and Münster 2015).

This article pursues this focus on specifically interspecies ethnography, and argues that we need to reconsider the cross-species continuities between humans and similarly sentient companion species while also considering how their lives have been jointly configured through their social, historical, and ecological intersections (Locke 2013, 2016a). It does so by attending to the affective aspects of an ethnographic apprenticeship as a mahout in the government stables of the Chitwan National Park, Nepal, an occasionally dangerous form of skilled custodial labor. Through focus on empathetic and embodied engagement with an elephant (hatti in Nepali) named Sitasma Kali, it concerns life in a community of humans and 
elephants so morally and practically entangled that it may be described as hybrid (Lestel, Brunois, and Gaunet 2006). It also considers the multiple, malleable, and culturally variable character of ideas about personhood, not always restricted to anthropic figurations. In so doing, I acknowledge that conceptions of personhood rooted in Western thought are deployed by the animal sciences to make moral and legal arguments for nonhuman personhood, that local understanding produces a figuration of personhood based on a logic of permeability between animals, persons, and gods, while also interrogating my intersubjective experience apprenticing as a mahout. I therefore explain how I was compelled to reconceive my research as an ethnographic study with two types of person-only one of which is human-by presenting an experiential account of a relationship forged across species boundaries. This represents a methodological disruption to the typically humanist constraints of ethnography, in that elephants not only came to represent subjective actors but also participating research informants.

The site for this interspecies relationship is the enclaved institution of the government elephant stable or sarkari hattisar, a regimented space where human and elephant lives are bound together in service to the imperatives of protected area management (Locke 2011a). The human occupational community that constitutes this institution draws on a long history in Nepal of capturing and managing elephants for trade, tribute, hunting, and ceremony (Locke 2011b). Physically enclosed and socially segregated, and with its own distinctive Hindu ritual practices, the hattisar represents a total institution since virtually all aspects of life are conducted together, under a single authority and according to a systematic schedule, deriving from a rational plan (Goffman 1961). However, comprising a hybrid occupational community of humans and elephants, whose handlers variously treat elephants as animals, as persons, and as gods, this may be better conceived as a multispecies total institution (Locke 2011a, 2013, 2016b). The particular hattisar at which I apprenticed-with the original objective of documenting the skilled practice and expert knowledge of a human occupational community-was the Khorsor Elephant Breeding Center. At this stable, pregnant females are brought to give birth, and their offspring are trained for working life in the National Parks and protected areas of Nepal's lowland Tarai (see the documentary film "Servants of Ganesh," Dugas and Locke 2010). This enables the government, as a signatory to the Convention on International Trade in Endangered Species (CITES), to maintain its population of working elephants now that it is no longer able to legally purchase elephants across national borders.

It is from this location among a community of breeding elephants and their handlers that I explore ideas of nonhuman personhood in relation to fieldwork experience, locally configured understandings, and the cognitive and behavioral animal sciences, three different but intersecting sites for figuring the significance of the subjective agency of elephants. This exploration of human-elephant companionship is also conceptually situated in relation to ethnoelephantology, an emerging framework for understanding multiple aspects of the human-elephant nexus through time and across space (Locke 2013). Inspired by ethnoprimatology, the interdisciplinary study of human-primate interactions (Fuentes 2010, 2012), it argues for recognition of the shared subjective agency of human and elephant, the generative sociality of their imbricated lives and landscapes, and the 
applicability of methodological perspectives from the social and natural sciences to better understand this kind of interspecies intersection (Locke 2013; Locke and Buckingham 2016). This partly involves recognition of the common concerns and practices of ethology and ethnography as ultimately similar forms of social and environmental research (Lestel, Brunois, and Gaunet 2006; Lestel, Bussolini, and Chrulew 2014), and hence an attempt to integrate multiple forms of disciplinary knowledge.

\section{Empathy, experience, and apprenticeship}

Ethnoelephantology also represents an attempt at theorizing an integrated framework for investigating the myriad interconnections that bind humans to free roaming, captive, and symbolic elephants through enterprises of power, wealth, worship, pleasure, and preservation. The use of the "ethno-" prefix then refers not to the constructed understandings of particular human groups, as with ethnobiology and its cognates, but to the consideration of anthropogenic influences that configure the ecological, physiological, and social aspects of nonhuman life (Fuentes 2010: 601). This approach to human-elephant relations contributes then to an interspecies strand of multispecies studies as an attempt at articulating "more-than-human" and sometimes also "not-just-animal" approaches to shared life. This work challenges the ontological binaries of humanism, with its polarities of nature and culture, human and animal, subject and object, that have served to sequester humanity in what many posthumanist and multispecies thinkers consider an epistemologically impoverished space of ecological segregation. However, it is crucial to appreciate that my personal, in situ conviction regarding nonhuman personhood that I discuss here preceded anthropological theorization, the emergence of multispecies ethnography, and my familiarity with posthumanist thinking, arising instead from the transformative intensity of fieldwork with more than one social species capable of expressing intentional agency and interspecies empathy.

In my experience of participant observation the sarkari hattisar elephants as well as humans came to fulfill the role of informant, leading me to question the Western idea that implicitly equates humanity with personhood. In Western modernity, the latter has been considered an exclusive attribute of the former as selfknowing, self-directing agents in social worlds (Taylor 1985). This had the effect of precluding the possibility of nonhuman individuals as decisive agents. Indeed, we can locate this Western conception of personhood in Enlightenment social contract theory, from which developed legal theories of moral responsibility concerned with the capacities by which individuals make informed decisions about the conditions of their existence (Collier, Maurer, and Suárez-Navaz 1997). At this time, too, I was unaware of the extent to which the animal behavioral and cognitive sciences blur the boundaries implied by this exceptionalist view, confirming elephants also as self-conscious, intentional, and social beings (Poole and Moss 2008). Philosopher Gary Varner, for instance, reviews evidence for autonoetic consciousness in elephants (which basically refers to a reflexive awareness of one's own life in the past, present, and future), which he uses as a proxy with which to infer and argue for the personhood of elephants (2008). Indeed, these criteria of self-consciousness 
from the animal sciences converge with these legal traditions of the sovereign individual in arguments for nonhuman personhood made by ethical theorists (Mitchell 1993). Such arguments are increasingly coming to court in order to secure legal rights for nonhuman animals, although they raise further questions for humans as the moral agents granting the status of personhood (Riddle 2014).

It is crucial, however, that in questioning the parameters of personhood, I did so without concern for authoritative legal judgment or scientific opinion, and that I did so through my ethnographic willingness to surrender my being and open myself to new modes of experience (Benedict 1948 in Rubenstein 2004: 1048). Indeed, Heidegger's notion of being-in-the-world depends on the claim that our practical involvement with a world that cannot be separated from the perceiving self comes prior to the actions of a cogitating ego (Willerslev 2007: 21). Only later did I focus my attention on local logics of personhood, and furnish my direct experience of engaging with elephants as persons with theoretical justifications. It was the primacy of experience that enabled me to initiate a process of mutual becoming (Haraway 2008) through which Sitasma and I attuned our bodies and our selves, only possible because I was granted the privilege of apprenticing as a mahout, or hattisare as they are known in Chitwan.

From the outset, my hosts expressed the conviction that I could never truly understand their working life unless I too became a hattisare. This not only coincided with my methodological convictions about fieldwork as a form of apprenticeship, and the limitations of verbal exposition in learning and acculturation (Bloch 1991: 194; Ingold 1993: 222), but also with my personal hopes for a project inspired by Mark Shand's account of the relationship he developed with an elephant named Tara that he rode across India (Shand 1991). However, I had to wait for access to the participatory experience that would admit me to the exclusive world of the hattisare. When the adikrit subba, the chief mahout, designated me to apprentice with Sitasma Kali, a 20-year-old female of good temperament who was always accompanied by her two-year-old son, Kha Prasad, I experienced a moment of ecstatic joy and excited anticipation. Sporting a finely waxed moustache and exuding confident authority, the adikrit subba, whom we all respectfully addressed as "section sahib" (since he is chief of the government's elephant section), granted me permission like any other edict a commanding officer might issue. Rather than merely tolerated, I now felt my presence in the hattisar was accepted, by the humans if not yet by the elephants.

I understood his authorization as an endorsement of the experiential aspirations I held for my research, realizing that with this momentous decision he had consolidated his position as patron of my research. No longer just a foreign researcher, I had now been admitted to the ranks as a novice handler, an honorary mahut, obliged to diligently participate in the corporeal practices of elephant care, and to obey the members of Sitasma's care team. This comprised Dipendra, her mahut, the lowest rank primarily responsible for keeping an elephant's stable space clean; Tej Narayan, her patchuwa or grass-cutter; and Ram Ekval, her phanet or driver/ trainer, as well as Ram Lotan, the phanet for Kha, who would have the responsibility of accompanying him through the transformative initiation of training when he reached the age of three. With my new status as something of a "privileged idiot," I was able to engage in the daily routines and interspecies encounters of life in the 
hattisar, to experience otherwise unobtainable camaraderie, and most crucially, to develop my own physical and emotional relationship with an elephant.

The exertions of hattisare labor in the stable, in the forests, grasslands, and rivers as well as on elephant back, not only enabled me to appreciate the rigors of the elephant handling profession but also to attempt to master new skills, including the sensual, embodied communication with nonhuman companions that only develops through sustained interaction between human and elephant selves. Few dispensations were made just because I was the foreign researcher. Thus, from the outset I had to ride Sitasma bareback; there would be no gada for me (a padded cushion made of sackcloth filled with dried grass) and certainly no hauda (a balustraded seat secured on top of a gada to provide passengers a safe and comfortable ride). Riding astride Sitasma's bony spine as she ambled along jungle trails and forded rivers was at first far from comfortable (better when loaded with bundles of cut grass), but it did allow me to learn the feel of her moving body and adapt my comportment to it. Indeed, the acquisition of a mutually attuned bodily proficiency represented one of the most crucial and foundational aspects of my apprenticeship with Sitasma. Later I would theorize this empathetic and embodied apprenticeship by drawing on Maurice Merleau-Ponty's notion of the body-schema (1962), Pierre Bourdieu's idea of the habitus as a system of acquired dispositions (1977, 1990; Acciaioli 1981; Crossley 2001), and Thorstein Gieser's argument for the role of empathy in apprenticeship learning (2008).

My forays into the forests on elephant back represented more than just participation in authentic forms of hattisare practice: it was also about the sensuality of touch in communicating with, caring for, and being cared for by Sitasma. When I sat in the more comfortable and more intimate driving position, her warm ears flapping on my bare legs, I would be drawn to the alluring divot between the hemispheres of her gently bobbing head. I would stroke the curiously coarse hairs there, and I would enjoy the warm breath from her occasionally probing trunk that seemed to signify affection. I also demonstrated attentive care by swatting the flies whose bites draw blood (elephants, as I learned, are not thick-skinned as commonly asserted, and as suggested by the obsolete taxonomic order pachydermata). In so doing, I appreciated that she was sacrificing the opportunity to cover herself with protective soil by carrying a rider. If I dropped my stick (kocha), which I carried to discipline her should the need arise (the ankus, or spiked hook is not used by Nepali hattisare), she would pick it up and hand it to me with her trunk. Such were the visceral delights and habits of affectionate care that characterized our kinesthetic union.

Vinciane Despret's examination of how scientists use their bodies when engaging the animals they observe is helpful here (2013). Discussing a range of cases, including the primatological fieldwork of Barbara Smuts and Shirley Strum among baboons, she argues that forms of embodied communication are crucial for establishing empathetic relations, which in turn are crucial for the understandings ethologists develop. Despret develops the notion of "embodied empathy," which is particularly useful for thinking about the affective relations I consider between Sitasma and me. Of course, for much of the twentieth century, techniques of "embodied empathy" were downplayed in the accounts of animal ethologists, since that would imply reciprocal interactions at variance with the purely observational ethos 
of the discipline. As Despret notes, these were transgressions for which Strum and Smuts attracted harsh critique, since they adopted the stance of an ethnographer as Strum herself admits, allowing themselves to be educated by their subjects through embodied interactions, just as I did as an anthropologist with Sitasma (albeit in a rather more tactile way, and in a context of shared dwelling with elephant individuals already acculturated to humans).

Even if it was not widely accepted at first, these primatologists' attempts to use their own bodies in order to participate with their subjects, particularly regarding learning and mimicking baboon body language, were not without precedent. For instance, Konrad Lorenz, a foundational figure in ethology, famously allowed geese and jackdaws to imprint on him. Precedent can similarly be found for the attempts of Smuts and Strum to make sense of animal perspectives rather than just behavior, as the "phenomenological biology" of Jakob von Uexküll testifies. Most significant is his umwelt theory of the perceptual worlds of meaningful dwelling that species construct and inhabit by virtue of the sensory apparatus, bodily capacities, and environmental affordances particular to them in their habitats (see von Uexküll 1957).

All of this has significant implications for multispecies ethnography, ethnoelephantology, and my interspecies apprenticeship. The case of Smuts and Strum indicates a blurring of the disciplinary practices of ethnography and ethology, the productive possibilities of which are explored by Dominique Lestel and his colleagues (Lestel, Brunois, and Gaunet 2006). More recently, Lestel and colleagues argue, rather provocatively, that ethology ought to be incorporated into the social sciences, or at least a version no longer exclusive to humans (Lestel, Bussolini, and Chrulew 2014). Setting aside this bold proposal of appropriation and disciplinary reconfiguration, this work helps establish a mandate for no longer restricting ethnography to human life, especially important for those works of multispecies ethnography that focus on intersubjective relations, and that seek to integrate traditionally divergent forms of disciplinary expertise. For myself, of course, I only belatedly realized the need to attend more closely to expertise concerning a species my anthropological training had not prepared me for. This contrasts with BaynesRock's work on humans and hyenas in Harar $(2013,2015)$, which was simultaneously informed by animal ethology and human ethnography from the outset. In addition to Lestel's arguments regarding "etho-ethnology" and "ethno-ethology" (2006), aspects of von Uexküll's approach seem similarly significant, resonating in the multispecies work of anthropologists like Eduardo Kohn, concerned with more-than-human semiosis in ecological systems (2013), and Tim Ingold, concerned with the perceptual interpenetrations and behavioral adjustments of shared dwelling, demonstrated with regard to humans and reindeer (2013).

Returning to my companionship with Sitasma, our intimate interactions revealed to me personal recognition, intentionality, playfulness, attentive concern, and an ability to convey preferences and desires. As I would learn, these are constituents of what animal behavioral scientists identify as empathic consciousness (Bates et al. 2008). And following Despret's argument, it was by virtue of the embodied relationship that developed between us that I was alerted to this. As a result of our tactile communication and the trusting bond it produced, even before investigating the discursive genealogy of Western personhood and the possibility 
of its extension beyond the human, I experienced Sitasma not just as an individual but also as a person, at least in operational terms. In this sense, I did so in a pretheorized way since my direct, affective experience was produced by immersion in joint, intersubjective action (see Ingold 1992). What had been originally conceived as an ethnographic study of human expertise in captive animal management could no longer be sustained in such constraining terms. An ethological impulse to attend to animal behavior intruded upon my research project, as did an urge to ethnographically incorporate my relationship with a nonhuman companion. Sitasma and the other elephants had not only become subjective actors but also informing participants with whom I developed the social relations necessary for communicative understanding. This challenged the humanist basis of ethnography that makes it ontologically ill equipped to treat nonhuman beings as ultimately anything but animate objects.

\section{Reverence, gift-giving, and identity}

Nutritional gifts for elephants were another aspect of my affective apprenticeship that warrants attention. Not only relevant to building rapport with and facilitating obedience from Sitasma, these gifts also provide insight into the reverential attitudes that inflect human relations with elephants in the hattisar. Every day we would make dana with the grass we had cut and transported from the interior of the National Park. These are bite-sized grass packages filled with unhusked rice, salt, and molasses. In the interests of nutritional prudence and a ritual acknowledgment of elephant divinity however, the salt and molasses would be left out on Tuesdays, the day of Mars, the planet associated with the elephant-headed god Ganesh, while at the nearby Sauraha hattisar these ingredients were also left out on Sundays, when posts commemorating dead elephants were ritually venerated. These packages represent a crucial part of the elephants' supplementary diet, which help mitigate the time captive elephants spend working rather than grazing, as they would in their free roaming state. However, they are also important as an item of exchange with which a handler mediates his relationship with his elephant. My initially clumsy attempts at making dana provoked laughter from my new human colleagues. I felt duty bound to invest my effort in perfecting their production though, since Ram Ekval, the phanet and chief of Sitasma's care team made it clear that these nutritional packages would be crucial for me to foster an effective relationship with Sitasma.

In India these grass packages are commonly called $k u c h i$, but it is highly significant that in Nepal they are called dana. Although dana means gift, it is different from a merely mundane gift or upavar. Rather, dana denotes a religious offering. This became acutely meaningful to me when a phanet named Satya Narayan made the following statement of apology during the training of a juvenile elephant called Paras Gaj: "We ride you as an inferior servant, but we know that you are a superior god" (Dugas and Locke 2010). It is understood that every elephant is imbued with the divine substance of Ganesh, a theriomorphic deity represented as a four-armed being with an elephant head. Combining the anthropoid with the elephantine, for hattisare the symbol of Ganesh might be seen to reflect the parallel and paradoxical 
identities of devotee and god, servant and master in relations between handlers and elephants.

Thus, the giving of dana as a "meal" in the afternoon after daytime grazing, and at other times as a "snack" to secure cooperation, should not merely be seen instrumentally as a "bribe" but also as an act of reverence for acknowledging the divinity inherent within the elephant, while also signifying your commitment to the companion upon whom your livelihood depends. Rather than representing an ideology that mystifies a purely transactional relationship, I found the meaning of dana for handlers was indicative of a relationship that binds human and elephant together in a condition of reciprocal mutuality. This gift is most certainly not the tainted "Indian gift" that transfers the sins of the giver, the gift that pays for ritual services (Parry 1986; Raheja 1988). Instead, this is the sacrificial gift presented to the gods, who are immune to the transfer of impurity. This gift literally and symbolically feeds one of their living embodiments, a contrast to typical Hindu worship ( $p$ uja) in which digestible gifts are presented to images of gods (devako murti), and then consumed as consecrated leftovers (prasad) (Fuller 1979).

Hattisare do not merely receive loyalty and obedience in exchange for preparing and giving dana (the production of which also depends on the elephant's labor in collecting the grass for their production); it is also one of many practices that engenders a loving commitment, part of that process of mutual becoming to which I earlier referred. A young mahut named Birendra explained: "Being without your elephant would be like chopping off your hand-it's because of our elephants that we can survive, and that's why we must love them." Birendra may be acknowledging his material dependence on his elephant for his livelihood, but he is also acknowledging how integral that relationship is to his social identity as a hattisare, and reciprocally, how important it is to discharge his duty to his elephant. The captive elephant is thus revealed as an icon of both livelihood and occupational identity, for which hattisare avoid distinguishing the sentimental from the instrumental.

\section{Autonomy, consciousness, and mutuality}

The profound mutuality of this interspecies relationship became increasingly evident as I learned other core duties of elephant care, the most important of which are taking your elephant to graze and to bathe. After early morning grass cutting, and the preparation of dana, hattisare would take the first of their two daily meals of rice and lentils (dal bhat). Then it would be time to head out into the forests, savannas, and rivers of the park in the heat of the day, returning mid-afternoon. During grazing we usually chose to team up with other elephant-handler teams, determined by intersecting networks of interpersonal relationships among elephants and among handlers. This was the primary situation for Sitasma and me to develop and sustain the embodied empathy of our interspecies relationship.

As in the vignette with which I began this article, upon mounting my elephant companion, I would reverentially touch Sitasma's flank with the first two fingers of my right hand before touching my forehead and my chest (signifying the heart), just as when one anoints oneself with tika powder as prasad (the consecrated leftovers from performing a devotional act of sacrificial worship). Ram Ekval explained to 
me that this was the hattisare way of acknowledging our elephant's divinity, and requesting the goodwill of Ganesh while riding his incarnation. Upon reflection, I came to realize that acts like these were not merely an aspect of the etiquette of human-elephant relations-they were also an implicit recognition of the elephant's autonomy, of their being-in-the-world, their capability to make their own decisions rather than just follow our commands.

Just as no interpersonal relationship among humans can be truly considered unconditional, so it is between elephants and mahouts. The elephant's commitment is conditional, but not just according to conventional understandings of Pavlovian positive reinforcement and other approaches to the behavioral processes and economic utilities of animal learning theory (Schultz 2006). There is more at stake than the fulfillment of an elephant's needs and appetites in exchange for obedience and cooperation. Such a purely instrumental view would only perpetuate the human exceptionalism arising from the human/animal dualism that has animated both humanist scholarship and the animal sciences. In such models of domination there is little conceptual space to accommodate the dynamic mutuality of the human-elephant relationship integral to Nepali hattisare practice and the interspecies community it produces.

Like the hattisare, I came to understand "my" elephant as a conscious person with desires not entirely dissimilar to my own, with whom I could develop a relationship involving meaningful, two-way communication, and crucially, as a being who could reject her human companion if she wished. Indeed, the unwritten social contract between human and elephant is typically severed as old age approaches, when the elephant chooses to retire itself through increasing absences from the stable. This is the time in their life when their final set of molars wear down, after which they will no longer be capable of digesting food. I saw this myself with an elephant named Chanchal Kali, an aging, almost blind elephant at the hattisar of the Biodiversity Conservation Center in nearby Sauraha, a hub for Chitwan ecotourism. Her absences were accepted with a degree of sadness, since their significance as a harbinger of her impending death were understood.

Just as it took me time to appreciate the implication of autonomy in the act of reverence when mounting your elephant, so too the language of driving initially misled me. Although we spoke in terms that seemed to imply a perspective of handler-directed control and domination, it was only later that I realized this linguistic framing served to obfuscate what was also understood in terms of dynamic mutuality. Again, it was my affective and corporeal experience apprenticing with Sitasma that clarified the status of such commentaries. As I began my driving training, the patient Ram Ekval showed me how to give instructions by applying pressure with my toes behind Sitasma's ears, that intimate space of sensual contact only experienced by an elephant's driver. With his broad, welcoming grin he explained the various vocal commands handlers also use, and how to discipline Sitasma with a strike of the stick on her forehead. This instruction seemed to confirm a relationship of domination, albeit one tempered by the sensual engagement of human and elephant bodies familiar with each other. However, we both knew that verbal instruction alone would be as sufficient as expecting someone to master riding a bicycle without first falling off. Thus, Ram Ekval was bound to let me try for myself. More than merely the mechanics of an animate machine to master though, 
mahouting with Sitasma represented an intersubjective relationship to be engendered. With such an affable temperament, she willingly let herself be driven by an inexperienced foreigner whom she had only known for a short time. It was within her power not to tolerate me if she did not want to, but gladly, she did. Instruction was then but a prelude to embodied and empathetic learning, which not only defies verbal exposition but also requires development of an interpersonal relationship between handler and elephant (see Gieser 2008).

Sitasma was teaching me, even elephantizing me a little. A wiggle of her head would inform me I was misapplying my toes, her insistence on turning left when I was trying to turn right during grazing would be revealed not as disobedience on her part but rather her way of directing me toward the plant matter she liked for food or medicine (on self-medicating practices among elephants see Piyadasa 1994: 472). I needed to know such things if we were to understand each other. By learning to be together we began operating with knowing synergy. The handlers confirmed this: of course your elephant teaches you, of course you have to develop an empathetic understanding of each other, because "elephants are just like people too." This was a sentiment I heard many handlers express on many occasions, and the treatment of elephants as merely servile, animate machines (cf. Ingold 1994: 8) was a trope of cautionary tales in which bad handlers get what they deserve. My revelations were old news to my human colleagues, but my excited commentaries evoked a recognition of shared experience resistant to verbal articulation, of someone just beginning to acquire aspects of their hattisare habitus, and hence someone who was beginning to experience their lifeworld as members of a shared, interspecies moral community.

This was a lifeworld characterized by the intensive practices of interspecies encounter within a multispecies total institution housing a hybrid community of humans and elephants, similarly conceived as persons. The patchuwa Bukh Lal, who worked with the mighty tusker Birendra Prasad (named after the Nepali King killed by his son in the royal palace massacre of 2001, see Baral 2002), revealed the totalizing character of life spent with an elephant companion: "I know my own elephant better than I know my own family." This was no surprise since he came from a once-forested district in the eastern Tarai, which has traditionally supplied recruits to the sarkari hattisar, even though the forests have dwindled and the local stables are long gone. His family home was more than a day's journey away. Bukh Lal was with Birendra every day, able to read his moods in ways I could not discern, and only reunited with his family a few times a year, during annual leave (bida). He could approach Birendra in ways that would be foolish for me to do, as I would dramatically learn for myself with a female elephant named Puja Kali, even when he was not in musth $(\operatorname{mada})$. This is a periodic state of hormonal excitation that can last a few months, during which a male becomes dangerous and unpredictable, his urge to procreate visibly evident, negating usual relational bonds of trust between handler and elephant. As Bukh Lal said, "At these times, he's out of control, he's not himself; he can't be held responsible for his behavior."

These situations notwithstanding, I was beginning to truly appreciate the possibilities of knowing intimacy between handler and elephant. The ritualized greeting I described in the vignette that began this article is instructive. Sitasma's act of "hugging" me with her trunk was regular, it was mutually meaningful, and unlike 
the supplicatory gesture of reverence I have also described, it was a practice she herself initiated. Besides the strictly ethological interpretation of this pleasing embrace that would suggest Sitasma was recognizing my smell, I was well aware that making sense of this encounter raised questions about anthropomorphic interpretation and the challenges of understanding interspecies sociality and communication. At this time, preceding the emergence of multispecies ethnography, and concerned as I was with expert knowledge and practice, I was most interested in how the other handlers understood this practice. They claimed they could read their elephant's body language and recognize acts of affection in their behavior toward us. For me, it was an affective act of trusting surrender that signified the empathetic connection we had developed.

The hattisare confirmed my interpretation of these regular and distinctive trunk probings as a greeting ritual: this was how some elephants were known to engage with human companions with whom they have a sustained, intimate, and dependent relationship. As my human colleagues pointed out, this was also a way for Sitasma to mark me as "her human" (usko manche). It confirmed the attainment of a trusting relationship, since I would be a fool to come into such close proximity unless I was confident of her benevolent attitude toward me. After all, an elephant can violently discard us like an unwanted toy if they wish. Indeed, I was told of a case in which this had happened. Five years before my arrival, Puja Kali, who resided next to Sitasma, had squashed her handler. Just as Bukh Lal excused Birendra's behavior during musth as "temporary insanity", this event was not blamed on Puja Kali's temperament but rather on the disrespectful behavior of her handler, who had fallen off her back in a drunken state. Significantly, this consensual defense of Puja Kali, either irritated or confused by her handler's irregular behavior, demonstrated that hattisare were willing to defend an elephant companion against a human colleague. This was perhaps indicative not only of the abhorrence of irreverence toward these gods in animal form but also of the commensurable valuation of human and elephant forms of life in the hybrid moral community of the hattisar.

The entangled loyalties of human and elephant social life were also evident in the way that networks of human-elephant relations were determined both by human-to-human and elephant-to-elephant relations. I catalogued my knowledge of the hattisare with respect to the human-elephant teams of which they were a part. This influenced the pattern of my interaction with the handlers. Who your elephant was at least partially determined which of your human colleagues you would mix with most. If your elephants were grazing friends, you would have greater reason to maintain friendly relations with each other. I was beginning to realize that me being "Sitasma's human" (sitasmako manche) raised more interesting questions than Sitasma being "my elephant" (mero hatti).

That greeting ritual between Sitasma and me did not merely confirm that trusting rapport had developed between us, it also signified my acquisition of a particular identity for her, and also more generally for the whole community of Khorsor elephants. Their own patterns of conspecific interactions, inflected by personal preferences not entirely dissimilar to those among humans, had great significance for their human companions. Understanding how inter-elephant relations articulate with inter-human relations through the coupling patterns that connect particular elephants to particular humans was another important aspect 
of my apprenticeship. This was dramatically illustrated for me one morning when I walked close to Sitasma's neighbor, Puja Kali, known to be an occasionally moody elephant. With a rapidity that surprised me, she came out from her tethering post and gave me a swift, reprimanding slap with her trunk. I was shocked by her speed, power, and accuracy. Wielded by Sitasma, the trunk had come to represent an instrument of loving connection, but wielded by Puja Kali, an elephant with whom I was not intimate, it represented a weapon of hostility.

Convinced of the potency of the lesson I had learned, an amused colleague remarked that in every future elephant encounter I should remember that I was marked as Sitasma's human (and again, this was the fault of my ignorance rather than cause to blame Puja Kali's temperament). It was my responsibility to learn that there was a history of hostility between Sitasma and Puja Kali, which would make me an enemy of Puja Kali by extension. Similarly, I was warned never to take Sitasma close to another female called Lakshmi Kali, since they too had a history of antagonism (with Sitasma bearing a scar on her haunch to prove it). The animosity between Sitasma and other elephants had an influence on my interaction with members of those elephants' human care teams. Since our interests diverged, we found ourselves likely to interact less.

Thus, through my own intimate, interspecies relationship I came to realize the importance of elephant life histories in relation to each other and in relation to hattisare. The career biography of a hattisare is intimately bound to that of his elephant, and these histories play a constitutive role in their interwoven social worlds, sometimes discrete, sometimes overlapping. In terms of the concerns of ethnoelephantology and multispecies studies, this illustrates the humanist problem in promoting a purely human history that denies the constitutive role of other species, to which Susan Nance responds with a call for a transspecies history (2013). However, the issue here is not just the agency of elephants but also their agency as intentional social beings. My basic familiarity with the philosophical problem of animal minds (e.g., Griffin 1984, 2001) meant that I knew I had to be cautious about making the apparently anthropomorphic attribution of personhood, unless of course I challenged the ontological assumptions upon which it relies (see Ingold 1994). In the field, though, circumspection seemed irrelevant, and I was yet to encounter Varner's argument for elephant personhood from the identification of elephants' temporal self-awareness (2008). I cared less about the propriety of scientific thinking and the politics of moral reasoning than I did the affective experience of an interspecies relationship with a captive elephant. At this time, it seemed more useful to understand the cultural logic by which the hattisare understood their elephants as persons of another kind.

\section{Hattisare conceptions of personhood}

This then, is what I set about investigating. By considering hattisare conceptions of nature, authority, and the logic of caste, their extended attribution of personhood beyond the human became intelligible, articulated in a way that emphasizes human-animal continuities without denying human-animal differences. Nature, as a domain exterior to inhabited dwellings and not ostensibly transformed by 
human activity (Ellen 1996), was not understood according to the dualistic modality of Western thought with its tradition of humanist scholarship. Following Philippe Descola (1996) and Eduardo Viveiros de Castro (1996), rather than a clear separation of the domains of human culture and nonhuman nature, I discerned a sociocentric understanding in which nature and society are subject to the same organizing logic. The logic in this case was articulated through the idiom of substance, considered by some as typical of Hindu and South Asian thought (Marriott 1976; Marriott and Inden 1977).

In a world in which all life shares substance that varies according to the ratio of its component qualities, the three humoral guna of satvas, rajas, and tamas, which can be transmuted as a result of the effect of action or karma, and which determine rebirth in the cycle of life, or samsara, it follows that the ontological boundaries between animality, humanity, and divinity are permeable. In previous existences we may have lived in animal form, but with the potential for godhood within us all, in a future existence we may be able to realize our intrinsically divine nature and ascend the hierarchy of being, just as a change of dietary and ritual practice has enabled social groups to redefine their place within caste hierarchies based on the idiom of ritual purity (Srinivas 1962). As Lawrence Babb remarks, the greeting of namaste (like the gesture of supplication upon mounting an elephant) may be translated as saluting that portion of god that dwells within you (1975: 52).

In this sociocentric and hierarchic world, the jungle, savannas, and rivers to which we daily drove with our elephants are conceived as potentially dangerous and unpredictable places, subject however to the rule of deities, most significant of which is Ban Devi, the goddess of the forest. By conducting sacrificial rituals, we acknowledged her sovereign authority, and appeased her potential wrath through the giving of gifts pleasing to her humoral "substance-nature" (alcohol, meat, money, feminine items of beautification), and thereby militated against the misfortunes she might cause us, such as attack by dangerous animals. Similarly, we performed rituals to petition the goodwill of Ganesh, whose "substance-nature" inhabits our elephants. Elephant training is a time when such practices are most essential, since it is imperative to acknowledge that the elephants we drive are also gods we worship (by giving sweets appropriate to Ganesh's "substance-nature," evident in myths about his appetite and his representation with a fat belly). It was understood that we had to request his forgiveness as a superior god in animal form being subordinated to the purposes of inferior humans.

This simultaneity of animality and divinity in elephants implies both low and high status in a hierarchic continuum of beings. Puzzling upon this led me to consider how integral the logic of caste was to the handlers' hierarchic and sociocentric conception of nature and being. The Nepali word for caste, a group of beings sharing the same substance-nature-i.e., guna composition-whose interactions with other groups traditionally had to be strategically and ritually mediated according to a rationale of purity, is jat, or in Hindi, jati. This word means type, kind, or even species (Marriott and Inden 1977; Burghart 1984: 116-18). Thus, I realized that for the handlers there was no problem in extending the logic of caste to elephants, it being as much an essentialist theory of kinds as a social theory of discrete, ranked groups (see Burghart 1978). Indeed, the Sanskrit genre of texts on elephantology, known as gaja sastra, which has parallels with oral traditions of practical elephant 
knowledge, recognizes eight ranked castes of elephant, understood in terms of guna composition (Edgerton 1931; Wakankar and Mhaiskar 2006; Locke 2008).

While nonhuman animals without sacred associations provide little incentive to transpose the idiom of natural kinds for figuring relations between social groups to relations between species, I realized that in the hybrid community of the hattisar, elephants provide particular incentive. As the recognized repository of both animal and divine substance, the elephant confounds the typical cosmic hierarchy of gods, humans, and animals. Hindu gods are understood and represented in anthropomorphic terms, and since the elephant is a god in animal form, it discloses a cultural logic by which handlers may think of their elephants as persons. However, these kinds of person-gods, humans, or otherwise-conceptually diverge from that of the Western tradition of the individual, a difference McKim Marriott attempted to convey with his concept of the "dividual" (Sharma 1990: 252). This consideration of nonbiotic entities recalls the cosmo-ecological approach of Vinciane Despret and Michel Meuret (2016) that includes gods, ancestors, and spirits in multispecies accounts of the forms of life that constitute worlds.

\section{Practical experience and animal ethology}

Even as my reflections and my inquiries brought this interpretation into focus, I knew it was crucial that neither the handlers nor I needed either set of ideas to understand the relationships with our elephant companions in terms of intersubjective relations. It seemed that irrespective of our culturally conditioned thinking, one could not resist recognizing elephant personalities. Practical experience taught us they have memories of prior experiences that influence their behavior and dispositions, that they can effectively communicate preferences to nonelephants, that they possess reasoning and problem-solving ability, and that they demonstrate loyalty and affection. To deny this would be a betrayal of the lifeworld of the hattisare as persons involved in a process of becoming with their elephant companions (see Haraway 2008).

As such, the ascription of personhood not only suggests an idiom of engagement, but also reflects a mode of highly personalized interspecies encounter. I was unconcerned, excited even, that it might seem that I was transgressing the injunction against anthropomorphism characteristic of most twentieth-century animal ethology. After all, one of the primary implications of Darwinian evolutionary biology has been to subvert the Cartesian segregation of humanity from animality, as Darwin controversially acknowledged in his 1871 work "The Descent of Man" (Willerslev 2007: 114). It is interesting, though, that the need remains to reaffirm the ontological insight regarding the evolutionary continuity of life. For example, Barbara Noske reminds us that ethological studies of primates, cetaceans, elephants, and wolves have proven that qualities usually considered uniquely human, such as sociality, intentionality, self-awareness, tool use, and even language, can also be found to varying degrees in our nonhuman relatives (1996). In response to the call to rethink the prejudice that insists on drawing a definitive line between us and them, cultural primatologist Frans de Waal has advanced the notion of "anthropodenial" (2000). If anthropomorphism is the overestimation of commonalities 
between human and nonhuman animals, then "anthropodenial" is the underestimation of such commonalities (Daston and Mitman 2005: 9).

\section{Conclusion}

The experience of interspecies apprenticeship I have documented here contributes to the ethnographic study of skilled learning while also raising significant ontological and methodological questions for anthropology. As a result of the empathetic and embodied relationship I developed with Sitasma Kali, I had to adapt my notions of apprenticeship learning, which at that time largely derived from a literature concerned with acquiring skills in communities of practice (Lave and Wenger 1991; Lave 1993; Wenger 1998). Rather than understanding mastery of a craft, such as Yemeni minaret building (Marchand 2001), Malian masonry (Marchand 2009), British furniture making (Marchand 2010), Gujarati ship-building (Simpson 2006), or Liberian Tailoring (Lave 1997), my challenge not only included the mastery of practical skills but also the development of an intimate working relationship with a sentient nonhuman being.

This intensely affective experience was so profoundly transformative that I was compelled to extend personhood itself: my apprenticeship became an endeavor in learning how to interact with a nonhuman intersubjectively, and to do so with communicative and empathetic efficacy. In embracing for myself the notion that elephants are like people too, through lived experience rather than philosophically reasoned conviction, as well as encountering hattisare make the same assertion, the question arises how to make anthropological sense of a challenge to key ontological assumptions about human uniqueness. Here, recent developments in the animal cognitive and behavioral sciences became theoretically relevant for analyzing the data of my field experience, providing support for insights gained from experiences of living and traveling with captive elephants in the streets, stables, jungles, and rivers of Chitwan. However, unlike the indigenous traditions of South Asian elephant knowledge and their literary codifications (Olivelle 2016), these were scientific traditions that had been initially configured to downplay continuities with humans.

On the other side of the divide between the natural and social sciences, by challenging the typical isomorphism of humanity and personhood, this account also reveals the epistemological limitations of Enlightenment Humanism to which modern ethnographic practice is intellectually indebted. As a methodology within the social sciences, ethnography has developed as a way to study human social life that, until recently, critics have found inadequate for incorporating nonhuman life. However, posthumanist scholarship critiques the ontological dualisms that oppose cultural humans to natural animals, posing key questions about the knowledge practices that constitute the disciplinary configuration of Western thought responsible for the divergence of the social and natural sciences. As a consequence, new syntheses are emerging that reveal the intersecting relevance of ethnology and ethology (Lestel 2006), friction between the domains of the social and the natural sciences (Lestel, Bussolini, and Chrulew 2014), and that extend anthropology by insisting that the entanglement of other life forms with human lives, landscapes, 
and technologies must be theoretically integrated into accounts of human existence (Kirksey and Helmreich 2010; Ingold 2013).

These new syntheses, the critical interrogation of ontological dualisms, the complementary analytic role of cultural ethology, and my transformative experience becoming a hattisare with Sitasma Kali, have all contributed to the development of ethnoelephantology: a new, interdisciplinary framework for studying human-elephant intersections. In anthropology, geography, and history, research is emerging that explores "the intersecting lifeworlds and environmental mutualities of human and elephant" (Locke 2013: 90). This includes, for example, elephants as agents in the constitution of transnational environmentalist networks, and in the shaping of local landscapes of wildlife conflict in Yunnan (Hathaway 2013: 152-84); the ambivalent intimacies of human-elephant collaboration in South Indian forest management (Münster 2016); elephants, alcohol, psychosocial suffering, and bureaucracy in Assam (Jadhav and Barua 2012); and elephant agency in the nineteenth-century American circus (Nance 2013). By demonstrating the shared, interspecies moral community that emerges from humans and elephants living and working together, this article suggests a need to rethink human-elephant relations in a way that recognizes their mutual agency as social actors as well as the possibility of treating nonhumans as research informants.

\section{References}

Acciaioli, Gregory. 1981. "Knowing what you're doing: A review of Pierre Bourdieu's outline of a theory of practice." Canberra Anthropology 4 (1): 23-51.

Babb, Lawrence. 1975. The divine hierarchy: Popular Hinduism in central India. New York: University of Columbia Press.

Baker, Julian. 2016. “Trans-species colonial fieldwork: Elephants as Instruments and participants in mid-nineteenth-century India." In Conflict, negotiation, and coexistence: Rethinking human-elephant relations in South Asia, edited by Piers Locke and Jane Buckingham, 115-36. Delhi: Oxford University Press.

Baral, Lok Raj. 2002. "Nepal in 2001: The strained monarchy." Asian Survey 42 (1): 198-203.

Bates, Lucy A., Phyllis C. Lee, Norah Njiraini, Joyce H. Poole, Katito Sayialel, Soila Sayialel, Cynthia J. Moss, and Richard W. Byrne. 2008. "Do elephants show empathy?" Journal of Consciousness Studies 15 (10-11): 204-25.

Baynes-Rock, Marcus. 2013. "Life and death in the multispecies commons." Social Science Information 52 (2): 210-27.

- 2015. Among the bone eaters: Encounters with hyenas in Harar. Philadelphia: University of Pennsylvania Press.

Bloch, Maurice. 1991. “Language, anthropology and cognitive science." Man, n.s., 26 (2): 183-98.

Bourdieu, Pierre. 1977. Outline of a theory of practice. Translated by Richard Nice. Cambridge: Cambridge University Press.

1990. The logic of practice. Translated by Richard Nice. Oxford: Polity Press. 
Burghart, Richard. 1978. "Hierarchical models of the Hindu social system." Man, n.s., 13 (4): 519-26.

. 1984. "The formation of the concept of nation-state in Nepal." Journal of Asian Studies 44 (1): 101-25.

Byrne, Richard, Philip J. Barnard, Iain Davidson, Vincent M. Janik, William C. McGrew, Ádam Miklósi, and Polly Wiessner. 2004. "Understanding culture across species." Trends in Cognitive Sciences 8 (8): 341-46.

Castree, Noel, Catherine Nash, Neil Badmington, Bruce Braun, Jonathan Murdoch, Sarah Whatmore. 2004. "Mapping posthumanism: An exchange." Environment and Planning A 36 (8): 1341-63.

Choy, Timothy K., Lieba Faier, Michael J. Hathaway, Miyako Inoue, Shiho Satsuka, and Anna Tsing. 2009. "A new form of collaboration in cultural anthropology: Matsutake worlds." American Ethnologist 36 (2): 380-403.

Collier, Jane, Bill Maurer, and Liliana Suárez-Navaz. 1997. "Sanctioned identities: Legal constructions on modern personhood." Identities 2 (1-2): 1-27.

Crossley, Nick. 2001. "The phenomenological habitus and its construction." Theory and Society 30 (1): 81-120.

Daston, Lorraine, and Gregg Mitman. 2005. "Introduction." In Thinking with animals: New perspectives on anthropomorphism, edited by Lorraine Daston and Gregg Mitman, 1-14. New York: Columbia University Press.

de Waal, Frans. 2000. "Anthropomorphism and anthropodenial: Consistency in our thinking about humans and other animals." Philosophical Topics 27 (1): 255-80.

Descola, Philippe. 1996. “Constructing natures: Symbolic ecology and social practice." In Nature and society: Anthropological perspectives, edited by Philippe Descola and Gísli Pálsson, 82-102. London: Routledge.

Despret, Vinciane. 2013. "Responding bodies and partial affinities in human-animal worlds." Theory, Culture, Society 30 (7-8): 51-76.

Despret, Vinciane, and Michel Meuret. 2016. "Cosmoecological sheep and the arts of living on a damaged planet." Environmental Humanities 8 (1): 24-36.

Dugas, Mark, and Piers Locke. 2010. Servants of Ganesh. 44 minutes. One World Films: Octapixx. https://www.youtube.com/watch?v=ICxjrCzSKPE.

Edgerton, Franklin. 1931. The elephant lore of the Hindus: The elephant-sport (matanga-lila) of Nilakantha. Delhi: Motilal Banarsidass.

Ellen, Roy. 1996. “The cognitive geometry of nature: A contextual approach.” In Nature and society: Anthropological perspectives, edited by Philippe Descola and Gísli Pálsson, 103-23. London: Routledge.

Fuentes, Agustin. 2010. "Naturalcultural encounters in Bali: Monkeys, temples, tourists and ethnoprimatology." Cultural Anthropology 25 (4): 600-24.

. 2012. "Ethnoprimatology and the anthropology of the human-primate interface." Annual Review of Anthropology 41:101-17. 
Fuentes, Agustin, and Eduardo Kohn. 2012. "Two proposals.” Cambridge Anthropology 30 (2):136-46.

Fuller, C. J. 1979. "Gods, priests and purity: On the relation between Hinduism and the caste system.” Man, n.s., 14 (3): 459-78.

Gieser, Thorstein. 2008. "Embodiment, emotion, and empathy: A phenomenological approach to apprenticeship learning." Anthropological Theory 8 (3): 299-318.

Goffman, Erving. 1961. Asylums: Essays on the social situation of mental patients and other inmates. London: Penguin.

Griffin, Donald R. 1984. Animal thinking. Cambridge, MA: Harvard University Press.

2001. Animal minds: Beyond cognition to consciousness. Chicago: University of Chicago Press.

Haraway, Donna. 2008. When species meet. Minneapolis: University of Minnesota Press.

Hathaway, Michael. 2013. "On the backs of elephants: Transnational environmentalism and elephant 'agency."' In Environmental winds: Making the global in southwest China, 152-84. Berkeley: University of California Press.

Ingold, Tim. 1992. "Culture and the perception of the environment." In Bush base, forest farm: Culture, environment, and development, edited by Elisabeth Croll and David Parkin, 39-56. London: Routledge.

1993. "The art of translation in a continuous world." In Beyond boundaries: Understanding, translation and anthropological discourse, edited by Gísli Pálsson, 210-31. Oxford: Berg.

- 1994. "Introduction." In What is an animal? edited by Tim Ingold, 1-16. London: Routledge.

_. 2013. "Anthropology beyond humanity." Suomen Antropologi / Journal of the Finnish Anthropology Society 38 (3): 5-23.

Jadhav, Sushrut, and Maan Barua. 2012. “The elephant vanishes: Impact of human-elephant conflict on people's wellbeing." Health \& Place 18 (6): 1356-65.

Kirksey, S. Eben, and Stefan Helmreich. 2010. “The emergence of multispecies ethnography." Cultural Anthropology 25 (4): 545-76.

Kohn, Eduardo. 2013. How forests think: Toward an anthropology beyond the human. Berkeley: University of California Press.

Latour, Bruno. 1998. “To modernize or to ecologize? That's the question.” In Remaking reality: Nature at the millenium, edited by Bruce Braun and Noel Castree, 221-42. London: Routledge.

Lave, Jean. 1993. "Situated learning in communities of practice." In Perspectives on socially shared cognition, edited by Lauren B. Resnick, John M. Levine, and Stephanie D. Teasley, 63-82. Washington, DC: American Psychological Association.

. 1997. "Tailored learning: Apprenticeship and everyday practice among craftsmen in West Africa." In The culture of acquisition and the practice of understanding. London: Lawrence Erlabum Associates. 
Lave, Jean, and Etienne Wenger. 1991. Situated learning: Legitimate peripheral participation. Cambridge: Cambridge University Press.

Lestel, Dominique. 2006. "Ethology and ethnology: The coming synthesis, a general introduction." Social Science Information 45 (2): 147-53.

Lestel, Dominique, Florence Brunois, and Florence Gaunet. 2006. "Etho-ethnology and ethno-ethology." Social Science Information 45 (2): 155-77.

Lestel, Dominique, Jeffrey Bussolini, and Matthew Chrulew. 2014. “The phenomenology of animal life." Environmental Humanities 5: 12548.

Lestel, Dominique, and Hollis Taylor. 2013. "Shared life: An introduction." Social Science Information 52 (2): 183-86.

Locke, Piers. 2008. "Captive elephant management, the Tharu and the Nepali state." IIAS Newsletter 49:14-15.

— 2011a. "The ethnography of captive elephant management in Nepal: A synopsis." Gajah 34:32-40.

- 2011b. "The Tharu, the Tarai and the history of the Nepali hattisar." European Bulletin of Himalayan Research 38:61-82.

— 2013. "Explorations in ethnoelephantology: Social, historical, and ecological intersections between Asian elephants and humans." Environment and Society: Advances in Research 4 (1): 79-97.

_.2016a. "Introduction: Conflict, coexistence, and the challenge of rethinking humanelephant relations." In Conflict, negotiation, and coexistence: Rethinking human-elephant relations in South Asia, edited by Piers Locke and Jane Buckingham, 1-28. Delhi: Oxford University Press.

2016b. "Animals, persons, gods: Negotiating ambivalent relationships with captive elephants in Chitwan, Nepal." In Conflict, negotiation, and coexistence: Rethinking human-elephant relations in South Asia, edited by Piers Locke and Jane Buckingham, 159-79. Delhi: Oxford University Press.

Locke, Piers, and Jane Buckingham, eds. 2016. Conflict, negotiation, and coexistence: Rethinking human-elephant relations in South Asia. Delhi: Oxford University Press.

Locke, Piers, and Ursula Münster. 2015. "Multispecies ethnography." Oxford Bibliographies Online, last modified November 30, 2015. http://www.oxfordbibliographies.com/view/ document/obo-9780199766567/obo-9780199766567-0130.xml.

Lowe, Cecilia, and Ursula Münster. 2016. “The viral creep: Elephants and herpes in times of extinction." Environmental Humanities 8 (1): 118-42.

Marchand, Trevor. 2001. Minaret building and apprenticeship in Yemen. Richmond: Curzon.

—. 2009. The Masons of Djenné. Bloomington: Indiana University Press.

2010. "Embodied cognition and communication: Studies with British fine woodworkers." Journal of the Royal Anthropological Institute 16:S100-S120.

Marriott, McKim. 1976. "Hindu transactions: Diversity without dualism." In Transaction and meaning: Directions in the anthropology of exchange, edited by Bruce Kapferer, 10942. Philadelphia: Institute for The Study of Human Issues. 
Marriott, McKim, and Ronald Inden. 1977. "Toward an ethnosociology of South Asian caste systems." In The new wind: Changing identities in South Asia, edited by Kenneth David, 227-38. The Hague: Mouton.

Merleau-Ponty, Maurice. 1962. Phenomenology of perception. London: Routledge \& Kegan Paul.

Mitchell, Robert. 1993. "Humans, nonhumans, and personhood." In The great ape project: Equality beyond humanity, edited by Paola Cavalieri and Peter Singer, 237-47. London: Fourth Estate.

Mullin, Molly. 1999. "Mirrors and windows: Sociocultural studies of human-animal relationships." Annual Review of Anthropology 28: 201-24.

Münster, Ursula. 2016. "Working for the forest: The ambivalent intimacies of human-elephant collaboration in South Indian wildlife conservation.” Ethnos 81 (3): 425-47.

Nance, Susan. 2013. Entertaining elephants: Animal agency and the business of the American circus. Baltimore: Johns Hopkins University Press.

Noske, Barbara. 1996. Beyond boundaries: Humans and animals. Montreal: Black Rose Books.

Ogden, Laura A., Billy Hall, and Kimika Tanita. 2013. "Animals, plants, people, and things: A review of multsipecies ethnography." Environment and Society: Advances in Research 4 (1): 5-24.

Olivelle, Patrick. 2016. "Science of elephants in Kauțilya’s Arthaśästra." In Conflict, negotiation, and coexistence: Rethinking human-elephant relations in South Asia, edited by Piers Locke and Jane Buckingham, 75-91. Delhi: Oxford University Press.

Panelli, Ruth. 2010. "More-than-human social geographies: Posthuman and other possibilities." Progress in Human Geography 34 (1): 79-87.

Parry, Jonathan. 1986. “The gift, the Indian gift, and the 'Indian gift.” Man, n.s., 21 (3): 456-67.

Piyadasa, H. D. Wasantha. 1994. “Traditional systems for preventing and treating animal diseases in Sri Lanka." Sri Lanka. Rev Sci Tech 13 (2): 471-86.

Poole, Joyce H., and Cynthia J. Moss. 2008. "Elephant sociality and complexity: The scientific evidence." In Elephants and ethics: Toward a morality of coexistence, edited by Christen Wemmer and Catherine Christen, 69-98. Baltimore: Johns Hopkins University Press.

Riddle, Dorothy. 2014. "Evolving notions of nonhuman personhood: Is moral standing sufficient?" Journal of Evolution \& Technology 24 (3): 4-19.

Raheja, Gloria Goodwin. 1988. The poison in the gift: Ritual, prestation, and the dominant caste in a north Indian village. Chicago: Chicago University Press.

Rubenstein, Steven L. 2004. "Fieldwork and the erotic economy on the colonial frontier." Signs: Journal of Women in Culture and Society 29 (4): 1041-71.

Schultz, Wolfram. 2006. "Behavioral theories and the neurophysiology of reward." Annual Review of Psychology 57 (1): 87-115.

Shand, Mark. 1991. Travels on my elephant. London: Penguin. 
Sharma, K. 1990. "Western sociology with Indian icing." Contributions to Indian Sociology 24 (2): 251-58.

Simpson, Edward. 2006. "Apprenticeship in Western India." Journal of The Royal Anthropological Institute 12 (1): 151-71.

Srinivas, M. N. 1962. “Sanskritization and Westernization." In Caste in modern India and other essays, edited by M. N. Srinivas, 42-62. Bombay: Asia Publishing House.

Taylor, Charles. 1985. “The person.” In The category of the person: Anthropology, philosophy, history, edited by Michael Carrithers, Steven Collins, and Steven Lukes, 257-81. Cambridge: Cambridge University Press.

Tsing, Anna. 2015. The mushroom at the end of the world: On the possibility of life in capitalist ruins. Princeton, NJ: Princeton University Press.

van Dooren, Thom, Eben Kirksey, and Ursula Münster. 2016. "Multispecies studies: Cultivating arts of attentiveness." Environmental Humanities 8 (1): 1-23.

Varner, Gary. 2008. "Personhood, memory, and elephant management." In Elephants and ethics: Toward a morality of coexistence, edited by Christen Wemmer and Catherine, Christen, 41-68. Baltimore: Johns Hopkins University Press.

Viveiros de Castro, Eduardo. 1996. "Images of nature and society in Amazonian ethnology." Annual Review of Anthropology 25:179-200.

von Uexküll, Jakob. 1957. "A stroll through the worlds of animals and men: A picture book of invisible worlds." In Instinctive behavior: The evolution of a modern concept, edited by Claire Schiller, 5-80. New York: International Universities Press.

Wakankar, Siddharth Yeshwant, and Vaidya B. Mhaiskar. 2006. Maharsi Palakapya's Gaja Sastram with Sanskrit commentary. Delhi: Bharitya Kala Prakashan.

Wenger, Etienne. 1998. Communities of practice: Learning, meaning, and identity. Cambridge: Cambridge University Press.

Whatmore, Sarah. 2006. "Materialist returns: Practising cultural geography in and for a more-than-human world." Cultural Geographies 13 (4): 600-609.

Willerslev, Rane. 2007. Soul hunters: Hunting, animism, and personhood among the Siberian Yukaghirs. London: University of California Press.

\section{La personne de l'éléphant; apprentissage affectif et terrain avec des informateurs non-humains au Népal}

Résumé : Dans ce rapport sur l'intimité inter-espèces dans une étable pour éléphants au Népal, jexplore non seulement les figurations humaines de la personne mais soutient l'idée d'une inclusion méthodologique des informateurs non-humains, en tant qu'acteurs dotés d'une subjectivité et en tant que participants dans la recherche ethnographique. J'explique comment mon expérience d'une relation de confiance avec une éléphante dans une communauté hybride d'humains et déléphants éclaira pour moi les limites conceptuelles de la focale humano-centrique de l'ethnographie et de son inadaptation pour étudier la socialité des rencontres interespèces. Afin de discuter la question de personne non-humaine, je présente les 
développements des études du comportement animal, tout en étudiant les logiques culturelles de l'attribution de personnalité aux éléphants par les mahouts népalais. Cette exploration de l'apprentissage, de la personne, de la rencontre affective, se situe dans la veine inter-espèces des études multi-espèces; il s'agit d'une contribution à l'ethno-éléphantologie, une approche interdisciplinaire des relations sociales, historiques et écologiques entre les hommes et les éléphants.

Piers Locke is senior lecturer in anthropology at the University of Canterbury, New Zealand, where he teaches Multispecies Studies and the Anthropocene. He has conducted ethnographic research on human-elephant relations in Nepal and Sri Lanka, and developed ethnoelephantology as an integrated framework for studying the social, historical, and ecological intersections of humans, elephants, and environments. He is the lead editor of Conflict, negotiation, and coexistence: Rethinking human-elephant relations in South Asia and is currently completing a monograph based on fieldwork with humans and elephants in The Chitwan National Park, Nepal.

Piers Locke Department of Anthropology University of Canterbury Private Bag 4800 Christchurch New Zealand piers.locke@canterbury.ac.nz 